\title{
Alphagan allergy may increase the propensity for multiple eye-drop allergy
}

SA Osborne, DMI Montgomery, D Morris and IC McKay

\begin{abstract}
Aims Since its introduction in 1996, brimonidine tartrate $0.2 \%$ ophthalmic solution (Alphagan, Allergan) twice daily has become established as an effective intra ocular pressure-lowering treatment. While the efficacy of Alphagan cannot be questioned, we gained the clinical impression that the drug has an unacceptably high rate of allergy. Of greater concern, we suspected that patients suffering from local Alphagan allergy had a higher rate of allergy to subsequently used topical preparations. We analysed data from a large scale study of glaucoma patients to establish whether our suspicions were correct.

Subjects and methods We have created a database of the entire glaucoma treatment histories for consecutive patients attending a single consultant's clinics (DMIM) at Glasgow Royal Infirmary between May 1999 and September 2001. All have undergone medical treatment for primary open angle glaucoma, ocular hypertension, or normal tension glaucoma. Patients with any other form of glaucoma, and patients in whom a full record of treatment was not available were excluded from the study.
\end{abstract}

Results Alphagan was discontinued due to allergy on 73 per 100000 patient treatment days. This was a far higher frequency than for other preparations. In patients allergic to both Alphagan and another preparation (Timoptol, Trusopt and Xalatan), the mean interval between the first and second allergy was shorter when Alphagan allergy occurred first. This was statistically significant in Timoptol and Trusopt cross-reactivity.

Conclusions Alphagan has high allergenicity, and may increase the likelihood of allergy to subsequently used preparations.

Eye (2005) 19, 129-137. doi:10.1038/sj.eye.6701441

Published online 9 July 2004
Keywords: alphagan; brimonidine; allergy; hypersensitivity; glaucoma

\section{Introduction}

Since its introduction in 1996, brimonidine tartrate $0.2 \%$ ophthalmic solution (Alphagan, Allergan Ltd, High Wycombe, Bucks) has become established as an effective intraocular pressure lowering agent.

While the efficacy of Alphagan cannot be questioned, we gained the clinical impression that the drug has an unacceptably high rate of allergy. Of even greater concern, we suspected that patients suffering from local Alphagan allergy had an unexpectedly high rate of allergy to subsequently used topical preparations.

We analysed data from a large cohort of glaucoma patients to establish whether our suspicions were correct.

\section{Subjects and methods}

We have undertaken a retrospective and ongoing study of consecutive patients attending a single consultant's clinics (D.M.I.M.) at Glasgow Royal Infirmary. All have undergone medical treatment for primary open-angle glaucoma (POAG), ocular hypertension (OHT), or normal tension glaucoma (NTG).

Complete ocular treatment histories have been collated for every eligible patient who attended clinics between May 1999 and September 2001. This 28-month data collection period ensured that virtually every patient in our glaucoma population who was eligible for entry would be included in the study.

Patients with any other form of glaucoma, and patients in whom a full record of treatment was not available were excluded from the study.

Patients included in the study had their casenotes reviewed, and all relevant information
North Glasgow University Hospitals, NHS Trust, UK

Correspondence: SA Osborne

Department of Ophthalmology Claremont Wing Royal Victoria Infirmary Queen Victoria Road NE1 4LP, UK Tel: +441912325131 E-mail: stuartosborne@ doctors.org.uk

Received: 3 November 2003 Accepted: 14 January 2004 Published online: 9 July 2004

None of the authors have any proprietary interest in any of the products named in this manuscript.

Some of the data included in this manuscript were presented as a poster at the Royal College of Ophthalmologists Annual Congress, Birmingham, 20th-22nd May 2003. 
was entered in a standard data form. Data entered in the form for each patient included the following: patient name/date of birth/sex/race; diagnosis at most recent clinic visit; starting treatment and date commenced; each stoppage of treatment, including the reason for the stoppage, the date of the stoppage, and the new treatment regimen instituted.

The date on which the data were last entered in the form was recorded, this corresponding with the patient's most recent clinic attendance.

\section{Results}

\section{Part 1. Description and definitions of the data}

The main data were arranged in a spreadsheet with the following structure. Each row (record) of the table represented one course of treatment using one drug at a constant dose in one eye of one patient. If the drug or dose were changed then a new record was created. Often there would be two almost identical records, one for each eye.

Out of 2788 records in the main data file, there were 1297 suitable for formal hypothesis testing in that they satisfied the following selection criteria:

1. They described only the first use of a given drug in a given patient. This restriction was necessary because previous use of the same drug could have had a major effect on the time taken to develop complications such as allergy.

2. They described the treatment of only one eye per patient. This restriction was necessary for formal testing of hypotheses because the tests used assume that the units of observation are all mutually independent and randomly sampled from a large homogeneous population.

Of these 1297 records, there were 1237 suitable for formal analysis of incidence of allergy because they also fulfilled criterion 3:

3. They related to drugs that on some occasions were stopped on account of allergy. The treatments not causing allergy were Diamox S.R., Nil, Other, Pilogel nocte, and Pilocarpine. Some of these perhaps failed to cause allergy because they were not often used.

There were 1297 records that satisfied criteria 1 and 2, and these were saved in a separate file and used for estimating incidence of complications. The smaller set of 1237 records as used for the Kaplan-Meier analysis of the incidence of allergy.

\section{Part 2. Demographics}

There were 463 patients in the study, 191 (41.25\%) of whom were male and $272(58.75 \%)$ female.

The mean patient age at the end of the data collection period was 71 years, 3 months and 11 days, with an age range of 32 years, 11 months and 20 days to 95 years, 1 month and 1 day.

All but two of the patients were Caucasian, one being of Asian, and one of African origin. In all, 309 patients had POAG, 96 had OHT, and 58 had NTG.

There was an average of six recorded courses of treatment per patient.

The length of a course of treatment until it was stopped or until the latest available information was recorded, varied from 1 to 5803 days, with a mean of 488 days, and a median of 273 days.

There were 20 different single drug regimens used, some used much more frequently than others. (Table 1).

\section{Part 3. Comparison of incidence of reasons for stopping treatment with different drugs}

Before carrying out the Kaplan-Meier analysis, a simple analysis was carried out on the selected data set (of 1297 records) to compare the incidence of various reasons for stopping therapy with a given drug. The findings are summarised in Table 2.

In order to compare different drugs fairly, the number of times treatment was stopped was divided by the total number of patient-treatment days. The results are presented in Table 3.

\section{Part 4. Kaplan-Meier analysis}

The Kaplan-Meier test is designed to test the null hypothesis that the curve showing the probability of some event occurring as a function of time after start of treatment is the same for two or more different treatments. The curves showing the kinetics of development of allergy for 10 different drugs are shown in Figure 1. Estimates of the mean time to develop allergy are shown in Table 4.

Part 5. Evidence of cross-reactions, indicated by occurrence of allergies to two or more different drugs in the same patients

To study cross-reactions, the main data file was used to generate Table 5 .

Associations between allergies to two drugs were then examined as in Table 6 .

This allows us to calculate a measure of association between each pair of allergies, as shown in Table 7. The 
Table 1 Drug codes and preservatives contained in each preparation

\begin{tabular}{|c|c|c|c|c|c|c|c|c|}
\hline DrugEdose code & Meaning & Drug only code & Selected drug code & Times used & 1 & 2 & 3 & 4 \\
\hline $\mathrm{A}$ & Alphagan $0.2 \%$ b.d. & $\mathrm{A}$ & 1 & 531 & $\mathrm{y}$ & $\mathrm{n}$ & $\mathrm{n}$ & $\mathrm{n}$ \\
\hline $\mathrm{Az}$ & Azopt b.d & $\mathrm{Az}$ & 2 & 50 & $\mathrm{y}$ & $\mathrm{y}$ & $\mathrm{n}$ & $\mathrm{n}$ \\
\hline $\mathrm{B}$ & Betoptic $0.5 \%$ b.d. & $\mathrm{B}$ & 3 & 273 & $\mathrm{y}$ & $\mathrm{y}$ & $\mathrm{n}$ & $\mathrm{n}$ \\
\hline BG & Betagan $0.5 \%$ b.d. & BG & 4 & 12 & $\mathrm{y}$ & $\mathrm{y}$ & $\mathrm{n}$ & $\mathrm{n}$ \\
\hline BS & Betoptic S $0.25 \%$ b.d. & BS & 5 & 269 & $\mathrm{y}$ & $\mathrm{y}$ & $\mathrm{n}$ & $\mathrm{y}$ \\
\hline C & Cosopt b.d. & C & 6 & 158 & $\mathrm{y}$ & $\mathrm{n}$ & $\mathrm{n}$ & $\mathrm{n}$ \\
\hline $\mathrm{D}$ & Diamox S.R. $250 \mathrm{mg}$ b.d. & $\mathrm{D}$ & & 34 & & & & \\
\hline $\mathrm{O}$ & Other (state $\mathrm{Tx}$ ) & $\mathrm{O}$ & & 33 & & & & \\
\hline PG & Pilogel nocte & PG & & 12 & $\mathrm{y}$ & $\mathrm{y}$ & $\mathrm{n}$ & $\mathrm{n}$ \\
\hline Pil 2 & Pilocarpine $2 \%$ b.d. & Pil & & 2 & & & & \\
\hline Pil 3 & Pilocarpine $2 \%$ t.i.d. & Pil & & 21 & & & & \\
\hline Pil 4 & Pilocarpine $2 \%$ q.i.d. & Pil & & 12 & & & & \\
\hline Pro & Propine $0.1 \%$ b.d. & Pro & 7 & 80 & $\mathrm{y}$ & $\mathrm{y}$ & $\mathrm{n}$ & $\mathrm{n}$ \\
\hline Т 0.25 & Timoptol $0.25 \%$ b.d. & $\mathrm{T}$ & 8 & 125 & $\mathrm{y}$ & $\mathrm{n}$ & $\mathrm{n}$ & $\mathrm{n}$ \\
\hline T 0.25 LA & Timoptol $0.25 \%$ LA o.d. & $\mathrm{T}$ & 8 & 70 & $\mathrm{n}$ & $\mathrm{n}$ & $\mathrm{y}$ & $\mathrm{n}$ \\
\hline Т 0.5 & Timoptol $0.5 \%$ b.d. & $\mathrm{T}$ & 8 & 105 & $\mathrm{y}$ & $\mathrm{n}$ & $\mathrm{n}$ & $\mathrm{n}$ \\
\hline T $0.5 \mathrm{LA}$ & Timoptol $0.5 \%$ LA o.d. & $\mathrm{T}$ & 8 & 87 & $\mathrm{n}$ & $\mathrm{n}$ & $\mathrm{y}$ & $\mathrm{n}$ \\
\hline Tru 2 & Trusopt b.d. & Tru & 9 & 263 & $\mathrm{y}$ & $\mathrm{n}$ & $\mathrm{n}$ & $\mathrm{n}$ \\
\hline Tru 3 & Trusopt t.i.d. & Tru & 9 & 87 & $\mathrm{y}$ & $\mathrm{n}$ & $\mathrm{n}$ & $\mathrm{n}$ \\
\hline$X$ & Xalatan nocte & $X$ & 10 & 563 & $\mathrm{y}$ & $\mathrm{n}$ & $\mathrm{n}$ & $\mathrm{n}$ \\
\hline
\end{tabular}

Preservatives 1, 2, 3, and 4 are benzalkonium chloride, disodium edetate, benzododecinium bromide, and boric acid, respectively.

values shown are the coefficient of association Phi. Perfect correspondence between two allergies would give $P h i=1$, and a perfect negative association would give $\mathrm{Phi}=-1$. The symbol * indicates that the data were too sparse to calculate a measure of association.

The statistical significances of these associations were tested by Fisher's exact test, which gave the following $P$ values (calculated as defined by Anscombe). The symbol * indicates that the data were too sparse to test for statistical significance. (Table 8).

Given that there were 20 measures of association that could be tested for statistical significance, we do not consider that any $\mathrm{P}$ value greater than 0.0031 should be considered significant. This criterion was derived by applying Holm's correction for multiple testing to give us $95 \%$ confidence in the above table taken as a whole. This leaves us with six $P$-values (shown in bold italic) that we consider to be significant.

In attempting to account for these six associations, we need to consider the possibility that the allergen is not in fact the main active ingredient, but the preservative benzalkonium chloride, which is present in the drugs that show significant associations.

This hypothesis might be tested by separating the patients treated with Timpotol into two groups: those treated with Timoptol b.d., which contains benzalkonium chloride, and those treated with Timoptol LA, which contains benzododecinium bromide instead.

In effect, the above analysis was repeated, distinguishing this time between Timoptol and Timoptol
LA. First a table was generated with one row per patient and one column per drug, as in Table 5.

Timoptol 0.25 LA was not considered because no patient developed allergy to it, so our test of preservative depends on any difference between Timoptol 0.5 LA on the one hand and Timoptol 0.25 or 0.5 on the other.

The new Phi coefficients of association are shown in Table 9.

It can be seen that Timoptol b.d., which contains benzalkonium chloride, showed in its pattern of allergic reactions a slightly stronger resemblance to Alphagan and to Betoptic than did Timoptol LA, which does not share any preservatives with these drugs. This is compatible with a hypothetical role of the preservative benzalkonium chloride in the allergic reactions observed. However, when the patients are subdivided into such small groups, there is no possibility that the associations involving Timoptol and Timoptol LA would be statistically significant, no matter how large the coefficient of association.

\section{Part 6. Evidence from kinetics of presentation of the second allergy}

The pairs of apparent cross-reactions that were associated with statistically useful numbers (ie, nine or more) of patients allergic to both drugs were selected for closer examination in the hope of distinguishing between two hypothetical reasons for the associations observed. 
Table 2 Number of times treatment stopped and reasons for stopping

\begin{tabular}{|c|c|c|c|c|c|c|c|c|c|c|c|c|c|c|}
\hline Drug & $\begin{array}{c}\text { No of } \\
\text { patients } \\
\text { treated }\end{array}$ & $\begin{array}{c}\text { Mean } \\
\text { duration of } \\
\text { treatment }\end{array}$ & $\begin{array}{l}\text { Total } \\
\text { patient- } \\
\text { days }\end{array}$ & $\begin{array}{c}\text { Not } \\
\text { recorded }\end{array}$ & Allergy & Compliance & $\begin{array}{c}\text { Disc } \\
\text { cupping }\end{array}$ & Other & Pressure & Side effects & Tachyphylaxis & Field loss & $\begin{array}{c}\text { Surgical } \\
\text { success }\end{array}$ & All \\
\hline A & 261 & 337.7 & 88140 & 0 & 64 & 7 & 1 & 8 & 22 & 30 & 10 & 0 & 17 & 159 \\
\hline $\mathrm{Az}$ & 28 & 114.2 & 3198 & 0 & 1 & 0 & 0 & 0 & 0 & 1 & 0 & 0 & 1 & 3 \\
\hline $\mathrm{B}$ & 120 & 932.7 & 111924 & 0 & 6 & 6 & 1 & 5 & 8 & 15 & 26 & 3 & 25 & 95 \\
\hline BG & 6 & 1173.2 & 7039 & 0 & 3 & 0 & 0 & 0 & 0 & 0 & 2 & 0 & 1 & 6 \\
\hline BS & 132 & 371.4 & 49025 & 0 & 4 & 4 & 6 & 3 & 37 & 13 & 20 & 1 & 6 & 94 \\
\hline $\mathrm{C}$ & 80 & 286.3 & 22904 & 0 & 9 & 0 & 0 & 1 & 6 & 6 & 3 & 0 & 3 & 28 \\
\hline $\mathrm{D}$ & 16 & 159 & 2544 & 0 & 0 & 0 & 0 & 6 & 2 & 0 & 0 & 0 & 7 & 15 \\
\hline $\mathrm{O}$ & 16 & 95.8 & 1533 & 0 & 0 & 0 & 0 & 2 & 2 & 3 & 0 & 0 & 3 & 10 \\
\hline PG & 6 & 35.8 & 215 & 0 & 0 & 0 & 0 & 0 & 1 & 2 & 0 & 0 & 1 & 4 \\
\hline Pil & 14 & 1088 & 15232 & 0 & 0 & 0 & 1 & 2 & 2 & 1 & 4 & 1 & 3 & 14 \\
\hline Pro & 34 & 793 & 26962 & 0 & 3 & 0 & 1 & 4 & 5 & 4 & 8 & 0 & 8 & 33 \\
\hline $\mathrm{T}$ & 151 & 837.6 & 126478 & 0 & 9 & 2 & 3 & 10 & 17 & 5 & 30 & 1 & 18 & 95 \\
\hline Tru & 156 & 494.9 & 77204 & 0 & 27 & 9 & 5 & 7 & 25 & 12 & 24 & 6 & 19 & 134 \\
\hline$X$ & 269 & 314.3 & 84547 & 1 & 14 & 2 & 0 & 4 & 6 & 6 & 1 & 2 & 21 & 57 \\
\hline
\end{tabular}

Table 3 Number of times treatment stopped per 100,000 patient treatment days and reasons for stopping

\begin{tabular}{|c|c|c|c|c|c|c|c|c|c|c|c|c|c|c|}
\hline Drug & $\begin{array}{l}\text { No of } \\
\text { patients } \\
\text { treated }\end{array}$ & $\begin{array}{c}\text { Mean } \\
\text { duration of } \\
\text { treatment }\end{array}$ & $\begin{array}{l}\text { Total } \\
\text { patient- } \\
\text { days }\end{array}$ & $\begin{array}{l}\text { Not } \\
\text { recorded }\end{array}$ & Allergy & Compliance & $\begin{array}{c}\text { Disc } \\
\text { cupping }\end{array}$ & Other & Pressure & Side effects & Tachyphylaxis & Field loss & $\begin{array}{c}\text { Surgical } \\
\text { success }\end{array}$ & All \\
\hline \multicolumn{15}{|c|}{ No. of times treatment stopped per 100,000 patient treatment days } \\
\hline A & 261 & 337.7 & 88140 & 0 & 73 & 8 & 1 & 9 & 25 & 34 & 11 & 0 & 19 & 180 \\
\hline $\mathrm{Az}$ & 28 & 114.2 & 3198 & 0 & 31 & 0 & 0 & 0 & 0 & 31 & 0 & 0 & 31 & 94 \\
\hline B & 120 & 932.7 & 111924 & 0 & 5 & 5 & 1 & 4 & 7 & 13 & 23 & 3 & 22 & 85 \\
\hline BG & 6 & 1173.2 & 7039 & 0 & 43 & 0 & 0 & 0 & 0 & 0 & 28 & 0 & 14 & 85 \\
\hline BS & 132 & 371.4 & 49025 & 0 & 8 & 8 & 12 & 6 & 75 & 27 & 41 & 2 & 12 & 192 \\
\hline C & 80 & 286.3 & 22904 & 0 & 39 & 0 & 0 & 4 & 26 & 26 & 13 & 0 & 13 & 122 \\
\hline $\mathrm{D}$ & 16 & 159 & 2544 & 0 & 0 & 0 & 0 & 236 & 79 & 0 & 0 & 0 & 275 & 590 \\
\hline $\mathrm{O}$ & 16 & 95.8 & 1533 & 0 & 0 & 0 & 0 & 130 & 130 & 196 & 0 & 0 & 196 & 652 \\
\hline PG & 6 & 35.8 & 215 & 0 & 0 & 0 & 0 & 0 & 465 & 930 & 0 & 0 & 465 & 1860 \\
\hline Pil & 14 & 1088 & 15232 & 0 & 0 & 0 & 7 & 13 & 13 & 7 & 26 & 7 & 20 & 92 \\
\hline Pro & 34 & 793 & 26962 & 0 & 11 & 0 & 4 & 15 & 19 & 15 & 30 & 0 & 30 & 122 \\
\hline $\mathrm{T}$ & 151 & 837.6 & 126478 & 0 & 7 & 2 & 2 & 8 & 13 & 4 & 24 & 1 & 14 & 75 \\
\hline Tru & 156 & 494.9 & 77204 & 0 & 35 & 12 & 6 & 9 & 32 & 16 & 31 & 8 & 25 & 174 \\
\hline$X$ & 269 & 314.3 & 84547 & 1 & 17 & 2 & 0 & 5 & 7 & 7 & 1 & 2 & 25 & 67 \\
\hline
\end{tabular}


Hypothesis 1: the associations arise because some patients are predisposed to develop allergies, even if the various allergens do not cross-react immunologically.

Hypothesis 2: the associations arise because pairs of drugs contain substances that both react with the same antibody molecules, so that one drug can induce allergy to the other.

These hypotheses are not necessarily exhaustive. There are other possible explanations for the apparent crossreactions.

If hypothesis 1 were the whole explanation, then patients who became allergic to both of a pair of drugs would probably develop the allergy to any one drug at much the same speed irrespective of whether this was the first or the second drug used. If hypothesis 2 were the whole explanation, then allergy to the second drug should occur much more quickly due to the presence of cross-reacting antibodies already formed during the first allergic response. The allergic response to the second

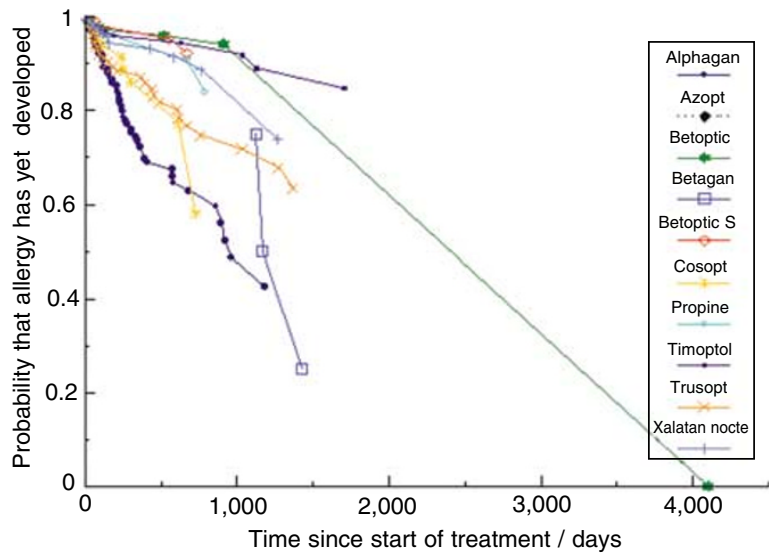

Figure 1 The curves showing the kinetics of development of allergy for ten different drugs used drug should therefore develop more quickly than in patients in whom that drug was used first.

The nine patients who developed allergy to both Alphagan and Timoptol were classified according to which drug was used first $\left(^{*}\right)$ Table 10.

The three in whom Alphagan was used first showed allergic reactions to Timoptol after 3, 40, and 122 days. In one patient the two drugs were used at the same time. In the five patients in whom Timoptol was used first, the allergy to timoptol developed after 183, 1126, 1705, 1767, and 5052 days. These two sets of intervals differ significantly as judged by Wilcoxon's rank-sum test $(P=0.037)$. This indicates that allergy to Timoptol showed up more quickly in patients previously allergic to Alphagan than in patients who became allergic to Alphagan subsequently.

The five in whom Timoptol was used first became allergic to Alphagan after 182, 305, 347, 396, and 1188

Table 5 Table formulated to assess drug cross-reactivity

\begin{tabular}{|c|c|c|c|c|c|c|c|c|c|c|}
\hline \multirow[b]{2}{*}{ Patient no. } & \multicolumn{10}{|c|}{ Drug code } \\
\hline & $A$ & $A z$ & $B$ & $B G$ & $B S$ & $C$ & Pro & $T$ & Tru & $X$ \\
\hline 1 & 1 & $*$ & $*$ & * & 1 & $*$ & $*$ & $*$ & $*$ & 0 \\
\hline 2 & $*$ & * & $*$ & * & * & $*$ & $*$ & $*$ & $*$ & 0 \\
\hline 3 & * & * & $*$ & * & 0 & $*$ & * & $*$ & * & 0 \\
\hline 4 & $*$ & * & 0 & * & $*$ & $*$ & * & $*$ & 0 & 0 \\
\hline 5 & * & $*$ & $*$ & * & 0 & $*$ & * & $*$ & $*$ & * \\
\hline 6 & 0 & 0 & $*$ & * & 0 & $*$ & * & $*$ & * & 0 \\
\hline 7 & $*$ & * & $*$ & * & $*$ & $*$ & * & $*$ & * & 0 \\
\hline 8 & $*$ & 0 & $*$ & * & * & $*$ & * & $*$ & * & 0 \\
\hline 9 & $*$ & $*$ & $*$ & * & 0 & $*$ & $*$ & $*$ & $*$ & * \\
\hline 10 & * & * & $*$ & * & * & $*$ & * & 0 & * & * \\
\hline 11 & 0 & $*$ & $*$ & $*$ & * & $*$ & $*$ & 0 & * & 0 \\
\hline 12 & $*$ & $*$ & 0 & * & 0 & $*$ & $*$ & $*$ & $*$ & * \\
\hline 13 & $*$ & * & $*$ & $*$ & 0 & $*$ & $*$ & $*$ & $*$ & * \\
\hline
\end{tabular}

$0=$ drug was used but allergy not reported;

$1=$ drug was used and stopped because of allergy;

* = this drug was not used in this patient.

Table 4 Estimates of mean time to develop allergy

\begin{tabular}{|c|c|c|c|c|c|c|}
\hline Drug no. & Drug name & Mean time to allergy/days & SE of mean & Lower $95 \%$ conf. limit & Upper $95 \%$ conf. limit & Median \\
\hline 1 & Alphagan & 809 & 39 & 732 & 885 & 966 \\
\hline 2 & Azopt & 42 & * & * & $*$ & $*$ \\
\hline 3 & Betoptic & 3892 & 102 & 3692 & 4093 & 4103 \\
\hline 4 & Betagan & 1289 & 87 & 1118 & 1459 & 1169 \\
\hline 5 & Betoptic S & 655 & 10 & 636 & 674 & * \\
\hline 6 & Cosopt & 644 & 30 & 586 & 702 & * \\
\hline 7 & Propine & 761 & 29 & 705 & 817 & * \\
\hline 8 & Timoptol & 1591 & 42 & 1509 & 1672 & * \\
\hline 9 & Trusopt & 1098 & 48 & 1003 & 1193 & * \\
\hline 10 & Xalatan & 1168 & 29 & 1110 & 1225 & * \\
\hline
\end{tabular}

*Indicates that there are not enough data to estimate a statistic. 
Table 6 Associations between allergies to two drugs

\begin{tabular}{|c|c|c|c|c|c|c|c|c|c|c|c|c|c|c|c|c|c|c|}
\hline \multirow[b]{2}{*}{$\mathrm{Az}$} & \multicolumn{2}{|c|}{$A$} & \multicolumn{2}{|c|}{$A z$} & \multicolumn{2}{|c|}{$B$} & \multicolumn{2}{|c|}{$B G$} & \multicolumn{2}{|c|}{$B S$} & \multicolumn{2}{|c|}{ C } & \multicolumn{2}{|c|}{ Pro } & \multicolumn{2}{|c|}{$T$} & \multicolumn{2}{|c|}{$\operatorname{Tr} u$} \\
\hline & $\begin{array}{r}13 \\
7\end{array}$ & $\begin{array}{l}1 \\
0\end{array}$ & & & & & & & & & & & & & & & & \\
\hline \multirow{2}{*}{ B } & 50 & 0 & 5 & 0 & & & & & & & & & & & & & & \\
\hline & 17 & 3 & 0 & 0 & & & & & & & & & & & & & & \\
\hline \multirow{2}{*}{$\mathrm{BG}$} & 2 & 1 & 0 & 0 & 1 & & & & & & & & & & & & & \\
\hline & 0 & 2 & 0 & 0 & 0 & 0 & & & & & & & & & & & & \\
\hline \multirow{2}{*}{ BS } & 57 & 0 & 6 & 0 & 21 & 1 & 0 & 0 & & & & & & & & & & \\
\hline & 16 & 5 & 0 & 0 & 0 & 0 & 2 & 0 & & & & & & & & & & \\
\hline \multirow{2}{*}{ C } & 39 & 2 & 1 & 2 & 26 & 2 & 0 & 0 & 20 & 1 & & & & & & & & \\
\hline & 11 & 6 & 0 & 1 & 1 & 0 & 0 & 0 & 2 & 0 & & & & & & & & \\
\hline \multirow{2}{*}{ Pro } & 17 & 3 & 2 & 1 & 11 & 0 & 1 & 0 & 3 & 0 & 9 & 0 & & & & & & \\
\hline & 5 & 0 & 0 & 0 & 1 & 0 & 1 & 0 & 0 & 0 & 1 & 0 & & & & & & \\
\hline \multirow{2}{*}{$\mathrm{T}$} & 50 & 0 & 5 & 2 & 22 & 1 & 1 & 0 & 14 & 1 & 29 & 1 & 21 & & & & & \\
\hline & 19 & 9 & 0 & 0 & 1 & 3 & 3 & 0 & 1 & 1 & 5 & 3 & 3 & 0 & & & & \\
\hline \multirow{2}{*}{ Tru } & 66 & 10 & 11 & 5 & 65 & 7 & 2 & 0 & 19 & 3 & 36 & 0 & 16 & 5 & 37 & 10 & & \\
\hline & 16 & 15 & 1 & 0 & 0 & 5 & 0 & 1 & 1 & 0 & 4 & 2 & 0 & 2 & 1 & 3 & & \\
\hline \multirow{2}{*}{$X$} & 110 & 4 & 19 & 2 & 65 & 2 & 1 & 0 & 57 & 4 & 39 & 4 & 21 & 1 & 65 & 6 & 78 & 4 \\
\hline & 52 & 10 & 1 & 0 & 3 & 2 & 1 & 1 & 4 & 1 & 6 & 3 & 3 & 0 & 7 & 2 & 21 & 5 \\
\hline
\end{tabular}

Each set of four numbers, represents numbers of patients classified below :

Top left : No. of patients treated with both drugs but allergic to neither

Bottom left : No. of patients treated with both drugs and allergic only to the one named above

Top right : No. of patients treated with both drugs and allergic only to the one named on the left

Bottom right : No. of patients treated with both drugs and allergic to both

days, while the three in whom Alphagan was used first became allergic to Alphagan after 28, 30 and 118 days.

The sets of intervals also differ significantly as judged by Wilcoxon's rank-sum test $(P=0.037)$. This is the opposite of the pattern seen in the previous paragraph. The data are compatible with the hypothesis that Alphagan can induce allergy to Timoptol but Timoptol does not induce allergy to Alphagan. Indeed, is seems as though prior use of Timoptol might suppress subsequent induction of allergy to Alphagan.

Another asymmetry in the relationship between these two drugs is that allergy to Alphagan occurred in the absence of allergy to Timoptol in 19 patients, but no patient treated with both drugs ever showed allergy to Timoptol in the absence of allergy to Alphagan.

A similar investigation of the relationship between Alphagan and Trusopt was carried out by studying those patients who have developed allergies to both these drugs (Table 11).

Among those patients in this set who were treated first with Alphagan, allergy to Trusopt began after 61, 62, 62 , and 79 days, whereas among those treated with Trusopt first, allergy to Trusopt began after 92, 92, 123, $396,457,487,609,668,862$, and 1370 days. These two sets of intervals differ significantly as judged by Wilcoxon's rank-sum test $(P=0.0057)$. This is compatible with the hypothesis that Alphagan induces allergy to Trusopt.
Among patients in this set treated first with Trusopt, allergy to Alphagan began after 28, 28, 61, 123, 183, 229, $305,862,924$, and 1188 days, while among those treated first with Alphagan, allergy to Alphagan began after 61, 153,275 , and 574 days. These two sets of intervals do not differ significantly as judged by Wilcoxon's rank-sum test or by the $t$-test. There was therefore no indication that Trusopt can induce allergy to Alphagan. This does not fit the hypothesis that the observed allergies are induced entirely by the preservatives.

The relationship between Alphagan and Xalatan nocte was also studied, not because the association was particularly convincing, but because there was a useful number, that is, 10 patients, who became allergic to both drugs. Unfortunately, all these patients except one were treated first with Alphagan, so the comparison is not very informative. Those treated first with Alphagan took $5,21,60,61,121,151,153,426$, and 762 days to develop allergy to Xalatan. The one patient who became allergic to Xalatan first took 580 days, which was above the average of the other intervals, but not statistically convincing.

Times taken to develop allergy to Alphagan in those treated with it first were $28,61,61,123,183,275$, 337,396 , and 682 days, and in the one patient treated first with Xalatan, it took 118 days to develop allergy to Alphagan, which was below the mean or the median of the other intervals, but not statistically convincing. 
Table 7 Measurement of association of allergies to two drugs

\begin{tabular}{|c|c|c|c|c|c|c|c|c|c|}
\hline & $A$ & $A z$ & B & $B G$ & $B S$ & C & Pro & $T$ & Tru \\
\hline $\mathrm{Az}$ & -0.158 & - & - & - & - & - & - & - & - \\
\hline B & 0.335 & * & - & - & - & - & - & - & - \\
\hline BG & 0.667 & * & * & - & - & - & - & - & - \\
\hline BS & 0.431 & * & $*$ & $*$ & - & - & - & - & - \\
\hline $\mathrm{C}$ & 0.402 & 0.333 & -0.051 & * & -0.066 & - & - & - & - \\
\hline Pro & -0.185 & $*$ & * & * & $*$ & * & - & - & - \\
\hline $\mathrm{T}$ & 0.483 & $*$ & 0.707 & $*$ & 0.433 & 0.454 & -0.075 & - & - \\
\hline Tru & 0.378 & -0.161 & 0.613 & 1.000 & -0.083 & 0.548 & 0.467 & 0.331 & - \\
\hline$X$ & 0.223 & -0.069 & 0.411 & 0.500 & 0.134 & 0.266 & -0.075 & 0.145 & 0.222 \\
\hline
\end{tabular}

Table 8 Statistical significance of cross-reactivity

\begin{tabular}{|c|c|c|c|c|c|c|c|c|c|}
\hline & $A$ & $A z$ & $B$ & $B G$ & $B S$ & C & Pro & $T$ & Tru \\
\hline $\mathrm{Az}$ & * & - & - & - & - & - & - & - & - \\
\hline B & 0.0104 & * & - & - & - & & - & - & - \\
\hline BG & * & * & * & - & - & & - & - & - \\
\hline BS & 0.00048 & * & * & $*$ & - & & - & - & - \\
\hline C & 0.0031 & * & * & * & 0.043 & - & - & - & - \\
\hline Pro & 0.75 & * & * & $*$ & * & * & - & - & - \\
\hline $\mathrm{T}$ & 0.000019 & * & 0.0027 & $*$ & 0.12 & 0.0123 & - & - & - \\
\hline Tru & 0.00016 & * & 0.000019 & $*$ & * & 0.0087 & 0.042 & 0.025 & - \\
\hline$x$ & 0.0044 & 0.55 & 0.011 & $*$ & 0.19 & 0.051 & * & 0.13 & 0.021 \\
\hline
\end{tabular}

Table 9 Measurement of association of allergies to two drugs, separating Timoptol from Timoptol LA

\begin{tabular}{|c|c|c|c|c|c|c|c|c|c|c|}
\hline & $A$ & $A z$ & B & $B G$ & $B S$ & $C$ & Pro & $T$ & T0.5LA & Tru \\
\hline $\mathrm{Az}$ & -0.158 & & & & & & & & & \\
\hline B & 0.335 & 0.000 & & & & & & & & \\
\hline BG & 0.667 & $*$ & * & & & & & & & \\
\hline BS & 0.431 & * & -0.000 & * & & & & & & \\
\hline C & 0.402 & 0.333 & -0.051 & $*$ & -0.066 & & & & & \\
\hline Pro & -0.185 & -0.000 & * & * & $*$ & * & & & & \\
\hline $\mathrm{T}$ & 0.624 & * & 1.000 & * & * & * & -0.125 & & & \\
\hline T0.5LA & 0.440 & 0.000 & 0.667 & * & 0.167 & 0.598 & $*$ & * & & \\
\hline Tru & 0.645 & $*$ & $*$ & * & $*$ & $*$ & $*$ & * & * & \\
\hline$x$ & 0.223 & -0.069 & 0.411 & 0.500 & 0.134 & 0.266 & -0.075 & -0.111 & 0.264 & * \\
\hline
\end{tabular}

The relationship between Alphagan and Xalatan is therefore compatible with the patterns seen in the other two pairs examined, and is also compatible with hypothesis 2 , but this pair of drugs provides only a very weak support for the hypothesis.

\section{Part 7. Surgery and allergy}

We were keen to establish whether glaucoma drainage surgery could increase the propensity for allergy to a subsequently administered preparation.

Table 12 shows that there was no statistically significant difference in allergy incidence between groups of patients who had undergone previous filtration surgery and those who had not.

\section{Discussion}

In our study, we found that Alphagan has high allergenicity when compared with other preparations, and that Alphagan allergy may increase the propensity for allergy to subsequently used preparations. What could be the explanation for our findings?

In 1997, Thompson et $a l^{1}$ hypothesised that the oxidative lability of apraclonidine and epinephrine could lead to hypersensitivity through covalent bonds formed 
Table 10 Patients who developed allergy to both Alphagan and Timoptol, classified according to which drug was used first $\left.{ }^{*}\right)$

\begin{tabular}{|c|c|c|c|}
\hline Patient & & Alphagan & Timoptol \\
\hline \multirow[t]{2}{*}{ A } & Date of first use & $21 / 10 / 1997$ & ${ }^{*} 21 / 12 / 1987$ \\
\hline & Duration of use & 1188 & 1767 \\
\hline \multirow[t]{2}{*}{ B } & Date of first use & 29/04/1998 & *29/06/1994 \\
\hline & Duration of use & 305 & 1705 \\
\hline \multirow[t]{2}{*}{$\mathrm{C}$} & Date of first use & 08/12/1998 & ${ }^{*} 08 / 06 / 1998$ \\
\hline & Duration of use & 182 & 183 \\
\hline \multirow[t]{2}{*}{$\mathrm{D}$} & Date of first use & ${ }^{*} 10 / 05 / 2000$ & $17 / 10 / 2000$ \\
\hline & Duration of use & 118 & 3 \\
\hline \multirow[t]{2}{*}{$\mathrm{E}$} & Date of first use & 06/01/1999 & 06/01/1999 \\
\hline & Duration of use & 90 & 90 \\
\hline \multirow[t]{2}{*}{$\mathrm{F}$} & Date of first use & ${ }^{*} 12 / 02 / 1998$ & $12 / 04 / 2000$ \\
\hline & Duration of use & 28 & 40 \\
\hline \multirow[t]{2}{*}{ G } & Date of first use & *21/04/1999 & 21/09/1999 \\
\hline & Duration of use & 30 & 122 \\
\hline \multirow[t]{2}{*}{$\mathrm{H}$} & Date of first use & 16/09/1999 & ${ }^{*} 16 / 11 / 1985$ \\
\hline & Duration of use & 347 & 5052 \\
\hline \multirow[t]{2}{*}{ I } & Date of first use & 04/03/1998 & *04/03/1996 \\
\hline & Duration of use & 396 & 1126 \\
\hline
\end{tabular}

with tissue macromolecules. However, they concluded that this was probably not the mechanism of clonidine or brimonidine allergy, as the latter two drugs were stable in enzymatic oxidative conditions.

This is supported by the lack of cross-reactivity in patients with allergy to apraclonidine who are subsequently treated with clonidine ${ }^{2}$ or brimonidine. ${ }^{3-5}$

Butler et $a l^{6}$ have suggested that 'adrenergic agents may reduce the volume of conjunctival cells, thereby producing a widening of the intercellular spaces through which potential allergens may reach the subepithelial tissues', causing allergy. This is supported by earlier findings by Alvarado et $a l^{7}$ in a study, which demonstrated that adrenergic agents decrease the cell volume of cultured human trabecular meshwork and Schlemm's canal endothelial cells. This, in turn, results in an increased fluid flow through a widened paracellular route. This effect can be blocked by simultaneously administered timolol. It is unknown whether this effect of timolol could be long-lasting.

This is consistent with our finding that Alphagan promotes the likelihood of allergy to a subsequently used preparation, but that Timoptol used prior to Alphagan seems to confer some protection against Alphagan allergy.
Table 11 Patients who developed allergy to both Alphagan and Trusopt, classified according to which drug was used first $\left(^{(*}\right)$

\begin{tabular}{|c|c|c|c|}
\hline Patient & & Alphagan & Trusopt \\
\hline \multirow[t]{2}{*}{$\mathrm{J}$} & Date of first use & *01/04/1998 & 18/01/1999 \\
\hline & Duration of use & 574 & 79 \\
\hline \multirow[t]{2}{*}{ K } & Date of first use & $21 / 10 / 1997$ & *21/03/1996 \\
\hline & Duration of use & 1188 & 92 \\
\hline \multirow[t]{2}{*}{$\mathrm{L}$} & Date of first use & 21/04/1998 & *05/03/1998 \\
\hline & Duration of use & 862 & 862 \\
\hline \multirow[t]{2}{*}{ M } & Date of first use & $* 22 / 06 / 1999$ & 22/08/1999 \\
\hline & Duration of use & 61 & 61 \\
\hline \multirow[t]{2}{*}{$\mathrm{N}$} & Date of first use & *01/04/1999 & $01 / 07 / 2000$ \\
\hline & Duration of use & 275 & 62 \\
\hline \multirow[t]{2}{*}{$\mathrm{O}$} & Date of first use & 06/02/1999 & *06/01/1998 \\
\hline & Duration of use & 28 & 396 \\
\hline \multirow[t]{2}{*}{$\mathrm{P}$} & Date of first use & 29/07/1997 & 29/07/1997 \\
\hline & Duration of use & 579 & 518 \\
\hline \multirow[t]{2}{*}{ Q } & Date of first use & 03/11/1997 & *03/01/1996 \\
\hline & Duration of use & 61 & 609 \\
\hline \multirow[t]{2}{*}{$\mathrm{R}$} & Date of first use & 29/04/1998 & *29/07/1994 \\
\hline & Duration of use & 305 & 1370 \\
\hline \multirow[t]{2}{*}{ S } & Date of first use & 10/06/1999 & *10/08/1998 \\
\hline & Duration of use & 183 & 487 \\
\hline \multirow[t]{2}{*}{$\mathrm{T}$} & Date of first use & 12/08/1997 & *12/06/1996 \\
\hline & Duration of use & 924 & 92 \\
\hline \multirow[t]{2}{*}{$\mathrm{U}$} & Date of first use & ${ }^{*} 01 / 04 / 1998$ & $01 / 07 / 1998$ \\
\hline & Duration of use & 153 & 62 \\
\hline \multirow[t]{2}{*}{ V } & Date of first use & $12 / 02 / 1998$ & *12/10/1997 \\
\hline & Duration of use & 28 & 123 \\
\hline \multirow[t]{2}{*}{ W } & Date of first use & 01/07/1999 & *01/07/1997 \\
\hline & Duration of use & 123 & 457 \\
\hline \multirow[t]{2}{*}{$x$} & Date of first use & $30 / 03 / 2000$ & $* 30 / 09 / 1996$ \\
\hline & Duration of use & 229 & 668 \\
\hline
\end{tabular}

Our data failed to determine, with statistical significance, whether the preservative used in an ophthalmic preparation has any effect on the likelihood of allergy to that preparation. It is likely that many of our patients developed allergy to the preservative in the preparation, rather than the active ingredient.

Whilst the authors cannot conclude with certainty that preservative does not account for the higher allergy incidence of Alphagan, the frequency of allergy with Alphagan use was significantly higher than with other 
Table 12 Patients categorised according to whether they did or did not receive filtration surgery before or at the time of starting therapy with a given drug for the first time, and according to whether that drug treatment was stopped because of allergy

\begin{tabular}{|c|c|c|c|c|c|}
\hline \multirow[b]{2}{*}{ Drug } & \multicolumn{2}{|c|}{$\begin{array}{l}\text { No surgery } \\
\text { before drug }\end{array}$} & \multicolumn{3}{|c|}{ Surgery before drug } \\
\hline & $\begin{array}{l}\text { Not stopped } \\
\text { for allergy }\end{array}$ & $\begin{array}{c}\text { Stopped } \\
\text { for allergy }\end{array}$ & $\begin{array}{l}\text { Not stopped } \\
\text { for allergy }\end{array}$ & $\begin{array}{l}\text { Stopped } \\
\text { for allergy }\end{array}$ & $\begin{array}{l}P \text { - } \\
\text { value }\end{array}$ \\
\hline A & 183 & 60 & 14 & 4 & 0.89 \\
\hline $\mathrm{Az}$ & 25 & 1 & 2 & 0 & 0.54 \\
\hline B & 112 & 5 & 2 & 1 & 0.075 \\
\hline BG & 3 & 3 & 0 & 0 & * \\
\hline BS & 119 & 4 & 9 & 0 & 0.62 \\
\hline $\mathrm{C}$ & 61 & 7 & 10 & 2 & 0.48 \\
\hline Pro & 29 & 3 & 2 & 0 & 0.59 \\
\hline $\mathrm{T}$ & 137 & 8 & 5 & 1 & 0.18 \\
\hline Tru & 117 & 26 & 12 & 1 & 0.36 \\
\hline$X$ & 237 & 13 & 21 & 1 & 0.81 \\
\hline
\end{tabular}

*Indicates not enough data to test for statistical significance.

preparations containing the same preservative, benzalkalonium chloride (see Tables 2 and 4). Whether this is due to an increased allergenicity of the active ingredient, brimonidine, or the combination of brimonidine and benzalkalonium chloride cannot be determined, as brimonidine has not been used in a preservative-free form.

This study did show that prior surgery appears to have little impact on the incidence of allergy to a subsequently used topical preparation.

The authors acknowledge that a strict definition of the clinical characteristics that constituted (and could be recorded as) an allergy was not made. This was due to the fact that much of the data were collected retrospectively from review of patients' case-notes. An allergy was simply recorded on the basis of the examining ophthalmologist's clinical impression, and ranged from an itchy follicular conjunctivitis to a fullblown reaction with chemosis and involvement of periorbital skin. In any event, the examining ophthalmologist considered the reaction to be of sufficient severity to warrant discontinuation of the medication. However, we feel that the data obtained, and the information arising from this, remain of significant value.

If our assertion is correct, that the occurrence of Alphagan allergy promotes subsequent allergy to other intraocular pressure lowering agents, this raises important concerns about the use of this drug in the management of glaucoma and ocular hypertension. By jeopardising tolerance of other medical therapies we may be compromising our long-term management options. Repeated allergies are a burden to patients in terms of discomfort, inconvenience, and the discouraging of compliance and are also an economic burden to the Health Service through increased frequency of casualty department and outpatient clinic attendances.

\section{References}

1 Thompson CD, Macdonald TL, Garst ME, Weise A, Munk SA. Mechanisms of adrenergic agonist induced allergy bioactivation and antigen formation. Exp Eye Res 1997; 64(5): 767-773

2 Geyer O, Schmidt KG, Pianka P, Neudorfer M, Lazar M. Clonidine provides an allergy-free alternative in glaucoma patients with proven allergy to apraclonidine. Graefes Arch Clin Exp Ophthalmol 2000; 238(2): 149-152.

3 Williams GC, Orengo-Nania S, Gross RL. Incidence of brimonidine allergy in patients previously allergic to apraclonidine. J Glaucoma 2000; 9(3): 235-238.

4 Shin DH, Glover BK, Cha SC, Kim YY, Kim C, Nguyen KD. Long-term brimonidine therapy in glaucoma patients with apraclonidine allergy. Am J Ophthalmol 1999; 127(5): 511-515.

5 Gordon RN, Liebmann JM, Greenfield DS, Lama P, Ritch R. Lack of cross-reactive allergic response to brimonidine in patients with known apraclonidine allergy. Eye 1998; 12(Part 4): 697-700.

6 Butler P, Mannschreck M, Lin S, Hwang I, Alvarado J. Clinical experience with the long-term use of $1 \%$ apraclonidine. Arch Ophthalmol 113; 1995: 293-296.

7 Alvarado JA, Franse-Carman L, McHolm G, Murphy C. Epinephrine effects on major cell types of the aqueous outflow pathway: in vitro studies/clinical implications. Trans Am Ophthalmol Soc 1990; 88: 267-282. 